\title{
FIRST LIZARD REMAINS (TEIIDAE) FROM THE MIOCENE OF BRAZIL (SOLIMÕES FORMATION)
}

\author{
ANNIE SCHMALTZ HSIOU \\ Seção de Paleontologia, Museu de Ciências Naturais, FZB-RS, Av. Salvador França, 1427, 90690-000, Porto Alegre, RS, \\ Brasil.anniehsiou@gmail.com
}

ADRIANA MARIAALBINO

CONICET, Departamento de Biología, Universidad Nacional de Mar del Plata, Funes 3250, 7600 Mar del Plata, Argentina. aalbino@mdp.edu.ar

JORGE FERIGOLO

Seção de Paleontologia, Museu de Ciências Naturais, FZB-RS, Av. Salvador França, 1427, 90690-000, Porto Alegre, RS, Brasil.jorge.ferigolo@fzb.rs.gov.br

\begin{abstract}
The South American Teiidae fossil record is restricted to the Cenozoic, and the most conspicuous remains were found in Early to Late Miocene of Argentina and Middle Miocene of Colombia and Peru, all represented by Tupinambinae lizards. Here, we describe a right fragmentary dentary and one dorsal vertebra collected in the Solimões Formation at the Talismã locality, situated on the Purus River, in the southwestern Brazilian Amazonia (Late Miocene). The material is tentatively conferred to the extinct genus Paradracaena. It represents the first record of lizards for the Neogene southwestern Brazilian Amazonia.
\end{abstract}

Key words: Teiidae, Tupinambinae, Solimões Formation, Miocene, southwestern Brazilian Amazonia.

\begin{abstract}
RESUMO - O registro fóssil de Teiidae para a América do Sul é restrito ao Cenozóico. Os fósseis mais significantes são encontrados a partir do Mioceno inferior ao superior da Argentina e Mioceno médio da Colômbia e Peru, principalmente representados pelos Tupinambinae. Neste trabalho descreve-se um fragmento de dentário direito e uma vértebra dorsal coletados em sedimentos da Formação Solimões, na localidade Talismã, alto rio Purus, sudoeste da Amazônia brasileira. O material é tentativamente conferido ao extinto gênero Paradracaena. Este material representa o primeiro registro de lagartos para o Neógeno do sudoeste da Amazônia brasileira.
\end{abstract}

Palavras-chave: Teiidae, Tupinambinae, Formação Solimões, Mioceno, sudoeste da Amazônia brasileira.

\section{INTRODUCTION}

The South American Miocene lizard record is mainly represented by the Teiidae family (Albino, 1996; Albino et al., 2006). The fossils include members of the Tupinambinae found from Early to Late Miocene of Argentina and Middle Miocene of Colombia and Peru. Teiid remains from the Early Miocene of Patagonia (Argentina) were assigned to Tupinambis (Brizuela \& Albino, 2004). Other lizard remains from the Early-Middle Miocene of southernmost Patagonia, that were considered extinct genera (Diasemosaurus Ameghino, 1893 and Dibolosodon Ameghino, 1893), have been recently reevaluated as belonging to the genus Tupinambis (Brizuela \& Albino, 2008a). Also, Albino et al. (2006) and Brizuela \& Albino (2008b) recognized the presence of Tupinambis or Crododilurus for the Middle Miocene of northwestern Patagonia. For the Late Miocene of central and northeastern Argentina the genus Tupinambis was also recorded (Ambrosetti, 1890; Estes, 1983; Donadío, 1984; Albino et al., 2006).

Besides the records of Argentina, Sullivan \& Estes (1997) reevaluated the material from La Venta Fauna (Middle Miocene of Colombia) reported by Estes (1961, 1983), and together with new materials, described the extinct tupinambine Paradracaena colombiana (closely related with the extant genus Dracaena), and a specimen probably referable to the extant Tupinambis. In addition, Pujos et al. (2009) described a dentary attributed to Paradracaena for the Middle Miocene of Peruvian Amazonia.

Recently, Hsiou et al. (2007) reported material of squamates from the Solimões Formation, Late Miocene of southwestern Brazilian Amazonia. As a continuation of this previous work, the main goal of this paper is to describe the first Teiidae remains from the Neogene of Brazil. 


\section{MATERIAL AND METHODS}

The teiid remains were collected at the locality of Talismã (08 48 '22'”S, 6848'12'”W), on the right hand bank upstream of the Purus River, Amazonas State, between the mouth of the Iaco River and the municipality of Manuel Urbano, Brazil (Figure 1A). The section is dominated by fine grain sediments, mainly silt and clay, with gypsum and calcite veins in the lower part, and manganese stains in the upper part, and the deposits are characterized by massive bedding with no evident lamination (Cozzuol, 2006) (Figure 1B). The Solimões Formation outcrops are known by their rich vertebrate faunas (see Cozzuol, 2006). They are from the Late Miocene age, as show by palynological data obtained in typical fossiliferous localities (Latrubesse et al., 2007), whose fossil vertebrates of southwestern Brazilian Amazonia are in this way attributable to the Huayquerian SALMA, which would correspond to the Late Miocene (Cozzuol, 2006; Latrubesse et al., 2007) or, possibly, reaching the Montehermosan (Late Miocene/Pliocene) (Latrubesse et al., 1997).
The specimens are stored at UFAC (Rio Branco, Acre State, Brazil), and include a fragmented right dentary and a well preserved dorsal vertebra. Skeletons of extant teiids were used for comparisons (Appendix). Osteological nomenclature follows Hoffstetter \& Gasc (1969) and Estes (1983). The systematic follows Presch (1974), Estes et al. (1988), and Nydam \& Cifelli (2002).

Institutional abreviations. MCN.D., Coleção Didática de Herpetologia, Museu de Ciências Naturais da Fundação Zoobotânica do Rio Grande do Sul, Porto Alegre; MZUSP, Museu de Zoologia da Universidade de São Paulo, São Paulo, Brazil; UFAC-PV, Coleção de Paleovertebrados do Laboratório de Pesquisas Paleontológicas do Departamento de Ciências da Natureza da Universidade Federal do Acre, Rio Branco, Acre, Brazil.

Osteological abreviations. mf, mental foramina; sy, symphysial surface; sbs, subdental shelf; mg, Meckel's groove; rp, replacement pits; tp, transverse process; ct, cotyle; $\mathbf{c d}$, condyle; poz, postzygapophysis; $\mathbf{t}$, tooth; $\mathbf{t c}$, tooth cavity; zy, zygantrum; ns, neural spine; syn, synapophysis; prz, prezygapophysis.
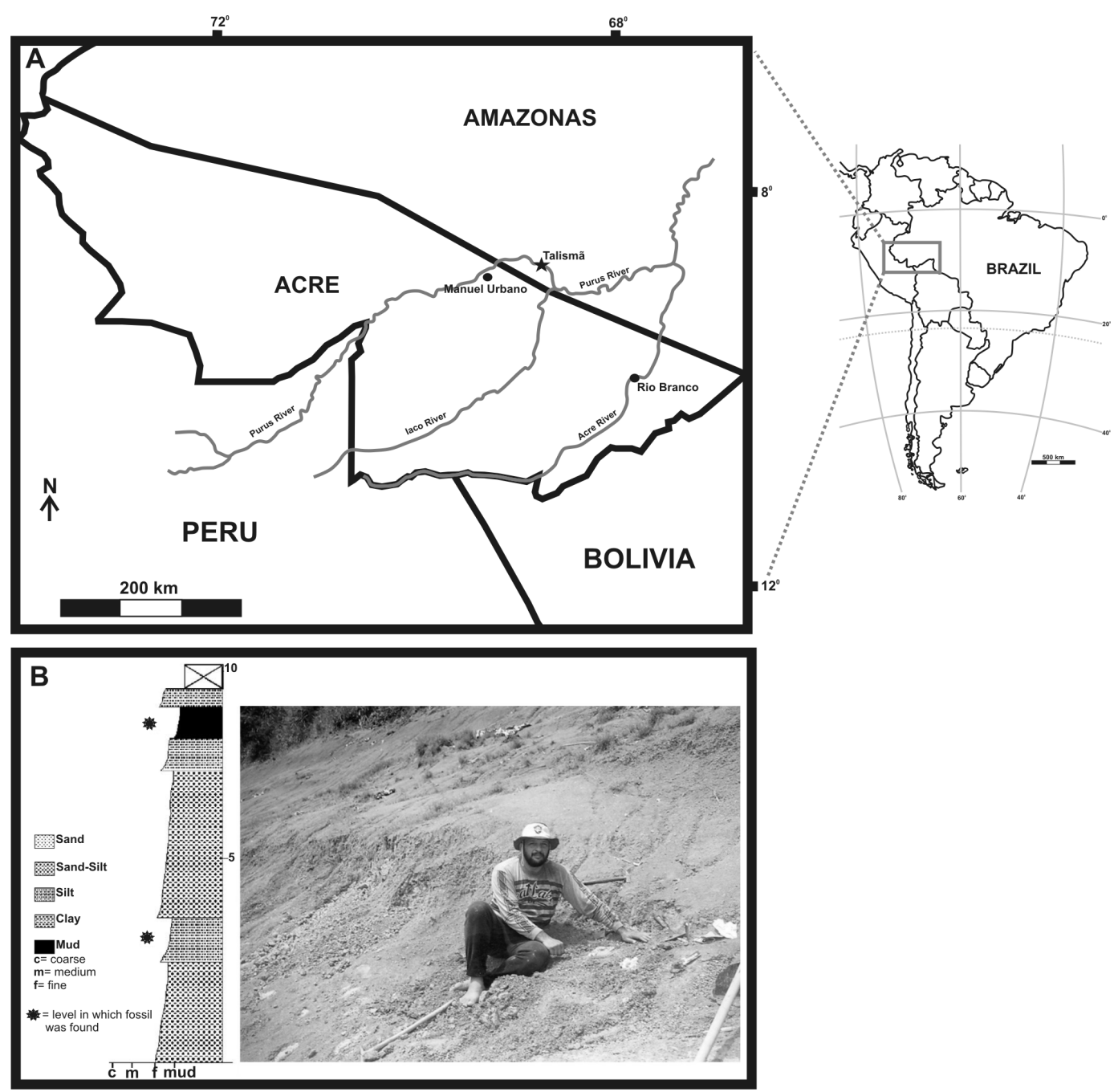

Figure 1. A, location map; B, stratigraphic profile of the fossiliferous locality Talismã (adapted from Cozzuol, 2006; photo taken from www.ufac.br). 


\section{SYSTEMATIC PALEONTOLOGY}

SQUAMATA Oppel, 1811

SCLEROGLOSSAEstes, de Queiroz \& Gauthier, 1988

SCINCOMORPHA Camp, 1923

TEIIOIDEA Estes, de Queiroz \& Gauthier, 1988

TEIIDAE Gray, 1827

TUPINAMBINAE Presch, 1974

Paradracaena Sullivan \& Estes, 1997

cf. Paradracena sp.

(Figures 2-3)

Referred material. UFAC-PV 3272, incomplete right dentary; UFAC-PV 2344, one dorsal vertebra.

Locality. Talismã locality, Upper Purus River, Amazonas State, Brazil.

Horizon and age. Solimões Formation, Late Miocene, southwestern Brazilian Amazonia.

Description. UFAC-PV 3272 is an anterior portion of a very fragmented right dentary preserved approximately until the middle of the tooth row and bearing ten tooth positions. The labial surface is deep, with five mental foramina. The subdental shelf is located ventrally close to the tooth bases, and is well developed up to the tenth tooth, converting to a thin shelf posteriorly. Lingually, despite the non-preserved splenial, Meckel's groove is widely open up to the mandibular symphysis; which is robust and shows a rugose articular surface, separated from the distal portion of the preserved dentary by a short constriction. Tooth implantation is subpleurodont with a thickening at the tooth basis, caused by deposition of cementum filling up the sulcus dentalis ("pseudothecodont" dentition of Nydam \& Cifelli, 2002). At least, ten tooth cavities are preserved, all teeth being broken or lost. Although the most anterior teeth are broken or missing, the cavities are slightly oblique sections and mostly of small size until the sixth tooth position, except for the fourth, that is larger. In occlusal view, the following four tooth cavities are more suboval in cross-section, labiolingually and mesiodistally enlarged, and with a slight oblique orientation. The ninth tooth shows a slight basal constriction, as a "neck" in lingual view. Between the subdental shelf and the seventh, ninth and tenth tooth bases, there are three deep subcircular cavities for replacement teeth. The three teeth inside these cavities display delicate ornamentations with radial striations converging in a central point. The crown seems flattened and mushroom-shaped.

The specimen UFAC-PV 3272 is a large and very well preserved dorsal vertebra, although the zygosphene and the

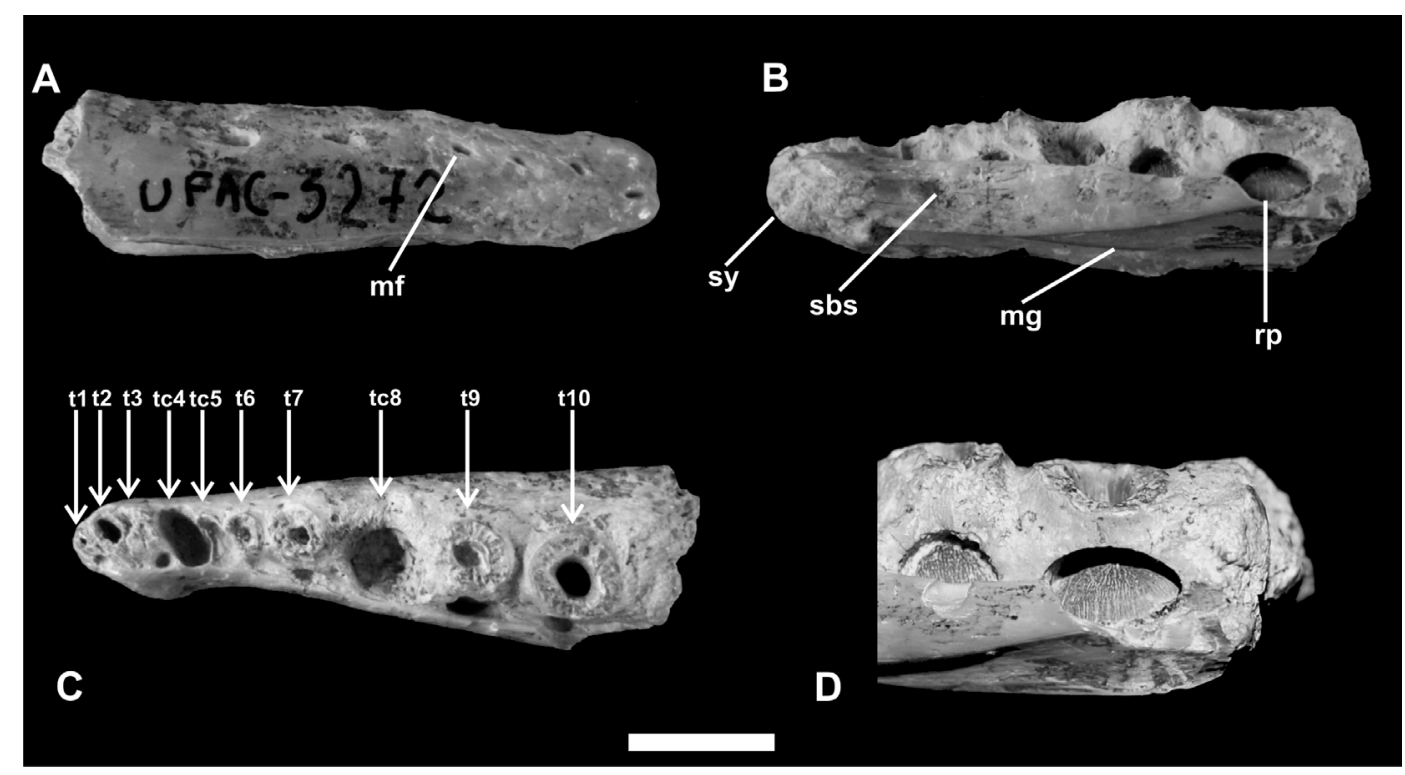

Figure 2. cf. Paradracaena sp., anterior portion of right dentary, UFAC-PV 3272: A, labial view; B, lingual view; C, occlusal view; D, detail of the replacement tooth and tooth crown. Scale bars $=20 \mathrm{~mm}$.

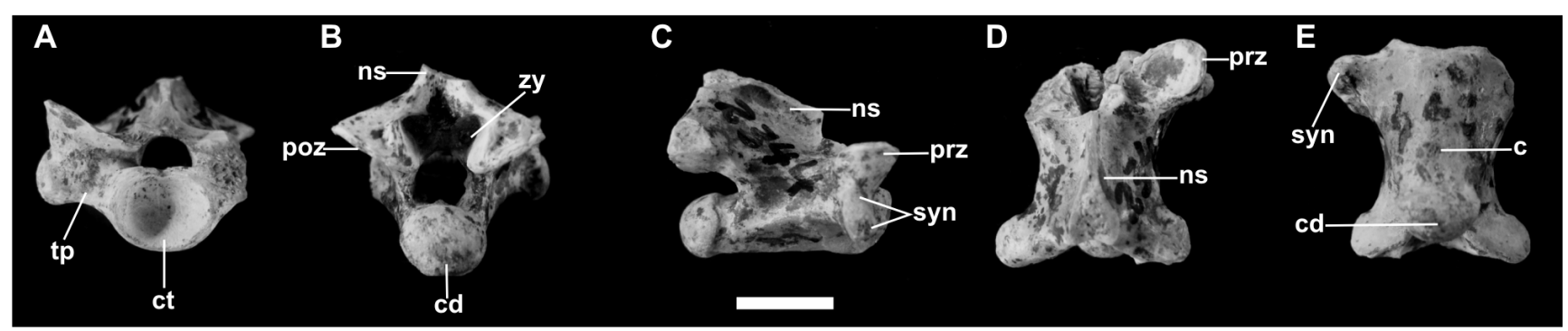

Figure 3. cf. Paradracaena sp., dorsal vertebra, UFAC-PV 2344: A, anterior view; B, posterior view; C, lateral view; D, dorsal view; E, ventral view. Scale bars $=10 \mathrm{~mm}$. 
left prezygapophysis are missing. It is deep, slender, and wide, but narrower in the middle. The right prezygapophysis is strongly inclined above the horizontal plane and set well dorsally respect to the neural canal. Its articular facet is broad, long, and oval shaped, with its main axis laterally oriented. The tip of the prezygapophysis reach the level of the zygosphene roof. The postzygapophyses are a little shorter than the prezygapophysis, well inclined dorsally and laterally oriented. The zygantrum is robust and deep. The neural canal, although partially broken, is triangular and trilobated. Although broken, the neural spine is somewhat high, anteroposteriorly long, and craneocaudally inclined. Apparently, the neural spine was in continuity with the anterodorsal edge of zygosphene. The transverse process projects beyond the prezygapophysis, and has a small rounded synapophysis at the end. It is not continuous with the prezygapophysis, and positioned much above the level of the ventral margin of the cotyle. The centrum is long, smooth, with a slightly anteroposteriorly development of the subcentral grooves. It is wider anteriorly than posteriorly, showing a well-marked precondylar constriction. The cotyle and condyle are large and slightly flattened dorsoventrally.

Discussion. The assignment of the specimens to the Teiidae is based on the following combination of characters: widely open Meckel's groove probably covered by a hypertrophied splenial, replacement teeth developing in deep subcircular cavities at tooth bases, deposit of cementum present on tooth bases, subpleurodont tooth implantation, presumably heterodonty because the most anterior tooth positions are smaller, development of the subdental shelf and sulcus dentalis present, and procoelic vertebra with zygosphenezygantral articulation (Hoffstetter \& Gasc, 1969; Presch, 1974; Estes et al., 1988; Gao \& Fox, 1991; Nydam \& Cifelli, 2002; Albino et al., 2006; Nydam et al., 2007).

The dentary UFAC-PV 3272 shows characters present in the extant Dracaena and the extinct Paradracaena. Although the specimen is incomplete, the teeth strongly enlarged, with a slight basal constriction observed in the ninth tooth, and the pseudothecodont condition, are characters shared by Dracaena and Paradracaena (Sullivan \& Estes, 1997; Pujos et al., 2009). Because the fossil specimen has ten tooth positions in a half dentary, it is possible to assume a higher number of teeth in its complete dental series, which contrast with the condition of Dracaena, which has a lower number of teeth (Pujos et al., 2009). Thus, the probable number of teeth and the suboval tooth sections are congruent with those of Paradracaena more than Dracaena (Pujos et al., 2009). Although the fragment is not as large as the half tooth row of the specimen of Paradracaena from the Pebas Formation (Peruvian Amazonia, Pujos et al., 2009), it is near the dimensions of the holotype of $P$. colombiana from La Venta Fauna of Colombia (Pujos et al., 2009). Nevertheless, this character shows intraespecific and ontogenetic variation, and cannot be considered of high taxonomic value at species level (Pujos et al., 2009).

Concerning the large trunk vertebra (UFAC-PV 2344), the features are the usual for the dorsal region of large
Tupinambinae, such as Tupinambis and Dracaena. However, the vertebrae of Dracaena and Tupinambis present a subtle difference. The vertebra UFAC-PV 2344 and those of Dracaena show a narrow and elongate neural arch, whereas in Tupinambis the neural arch is relatively shorter (pers. obs.). Although the comparative material of Dracaena is scarce, preventing our assessment of vertebral variation, the resemblance of the fossil vertebra with those of Dracaena suggest a closer relationship with this genus than with Tupinambis. Taking into account that the dentary specimen coming from the same level and locality is remarkably similar to Paradracaena, which is considered the sister taxon of Dracaena, the vertebra UFAC-PV 2344 is also considered as belonging to the same genus and co-referred tentatively to Paradracaena.

\section{FINAL CONSIDERATIONS}

The Brazilian Teiidae fossil record is limited. Some contributions of Paula-Couto (1949, 1958) and Estes (1970, 1983 ) for the Early Eocene of São José de Itaboraí mention the presence of the family, which was also documented by Estes \& Price (1973), Estes \& Báez (1985) and Albino (1996). Recently, Carvalho (2001, unpublished data), based on some materials already mentioned by Estes $(1970,1983)$, recognized several fossil lizards for this locality, also including indeterminated Teiidae. Later, Camolez (2006, unpublished data), working in caves and rocks of central-west and northeastern regions of Brazil, reported the most diverse fauna of lizards from the Late Pleistocene-Holocene, with several taxa correlated with the recent Brazilian herpetofauna. This work recognized many teiid lizards, such as Ameiva, Cnemidophorus and Tupinambis. Other previous works also have been reported teiid lizard remains for the southeast region (Estes, 1983; Souza-Cunha \& Magalhães, 1986). Up to now, only one fossil species was formally described for the Late Pleistocene of Brazil, Tupinambis uruguaianensis, from the Touro Passo Formation, Rio Grande do Sul State (Hsiou, 2007).

The presence of fossil specimens referable to the extinct Paradracaena represents the first record of lizards for the Late Miocene of southwestern Brazilian Amazonia, as well as the earliest record for the Neogene of Brazil. Nowadays, the extant genus Dracaena is a large, semi-aquatic teiid, represented by two species, both occur in swamps environments, with large rivers and dense vegetation (Krause, 1985); D. guianensis along the Amazonia Basin, and D. paraguayensis in Mato Grosso State and Paraguay (Vanzolini \& Valencia, 1965; Ávila-Pires, 1995). The habits of Paradracaena would have been similar (Pujos et al., 2009). This statement could support the hypothesis proposed by Latrubesse et al. $(1997,2007)$ that a large fluvial megafan complex would be present in the Late Miocene of the Solimões Formation. The environment proposed for the region is suggested by the presence of vertebrate fauna (rodents, crocodiles, turtles, freshwater fish and boid snakes) and palynological data that indicate open areas and forest galleries along rivers, swamps, and shallow lakes that would be subject 
to variation in the water level in a seasonal dry-humid tropical climate (Latrubesse et al., 2007; Hsiou \& Albino, 2009). Thus, the record reported here could be suggesting faunal similarities between the Solimões Formation in Brazil, the Pebas Formation in Peru, and the La Venta fauna in Colombia (Villavieja and La Victoria formations). The Miocene paleoenvironment proposed for these regions is very similar, although there is a temporal difference, where La Venta and Pebas Formation are considered as Middle Miocene age, while Solimões Formation is attributed to the Late Miocene. Besides, the predominance of tropical elements, as well as the development of fluvial systems (Kay \& Madden, 1997; Latrubesse et al., 1997, 2007; Antoine et al., 2007) is coincident with the presumable lifestyle and distribution of Paradracaena.

\section{ACKNOWLEDGMENTS}

The authors wish to thank for the financial support provided by $\mathrm{CNPq}$ (Conselho Nacional de Desenvolvimento Científico e Tecnológico) to ASH for studying at Universidade Federal do Rio Grande do Sul (PPGGeociências/UFRGS). The authors are also grateful to J.P. Souza-Filho, M.B. de Souza, and A. Maciente (UFAC) for loan of the fossil material; to H. Zaher (MZUSP) for the permission to visit the herpetological collections; to M.L. Araújo and M.L.M. Alves (MCN/FZBRS) for the loan of the Tupinambis specimens; to S. Brizuela for the photos of Dracaena and Crocodilurus specimens; and to C. Stolling for the English revision. We also thanks to R.L. Nydam and S. Apesteguía for their careful reviews and helpful suggestions.

\section{REFERENCES}

Albino, A.M. 1996. The South American Fossil Squamata (Reptilia: Lepidosauria). Münchner Geowissenschaftliche Abhandlungen A, 30:185-202.

Albino, A.M.; Brizuela, S. \& Montalvo, C. 2006. New Tupinambis remains from the Late Miocene of Argentina and a review of the South American Miocene teiids. Journal of Herpetology, 40(2):206-213.

Ambrosetti, J.B. 1890. Observaciones sobre los reptiles fósiles oligocenos de los terrenos terciarios antiguos del Paraná. Boletín de la Academia Nacional de Ciencias de Córdoba, 10:409-426.

Ameghino, F. 1893. Sobre la presencia de vertebrados de aspecto Mesozóico en la Formación Santacruceña de Patagonia Austral. Revista del Jardín Zoológico de Buenos Aires, 1:75-84.

Antoine, P.O.; Salas-Gismondi, R.; Baby, P.; Benammi, M.; Brusset, S.; de Franceschi, D.; Espurt, N.; Goillot, C.; Pujos, F.; Tejada, J. \& Urbina, M. 2007. The Middle Miocene (Laventan) Fitzcarrald Fauna, Amazonian Peru. Cuadernos del Museo Geominero, Instituto Geológico y Minero de España, 8:19-24.

Ávila-Pires, T.C.S. 1995. Lizards of Brazilian Amazonia (Reptilia: Squamata). Zoologische Verhandelingen, 299:1-176.

Brizuela, S. \& Albino, A.M. 2004. The earliest Tupinambis teiid from South America and its palaeoenvironmental significance. Journal of Herpetology, 38(1):113-119.

Brizuela, S. \& Albino, A.M. 2008a. Re-evaluation of the type material of "Diasemosaurus occidentalis" Ameghino and
"Dibolosodon typicus" Ameghino (Squamata: Teiidae) from the Miocene of Argentina. Journal of Vertebrate Paleontology, 28(1):253-257.

Brizuela, S. \& Albino, A.M. 2008b. Tupinambine teiids from the middle Miocene of north-western Patagonia (Argentina). Amphibia-Reptilia, 29:425-431.

Camolez, T. 2006. Levantamento, identificação e descrição da fauna de Squamata do Quaternário brasileiro (Lepidosauria). Programa de Pós-graduação em Ciências Biológicas (Zoologia), Universidade de São Paulo, M. Sc. thesis, 224 p.

Camp, C.L. 1923. Classification of the lizards. Buletin American Museum of Natural History, 48:289-481.

Carvalho, A.B. 2001. Estudo taxonômico dos "lagartos" fósseis (Lepidosauria: Squamata) da Bacia de São José de Itaboraí (Paleoceno), Estado do Rio de Janeiro. Programa de Pós-Graduação em Zoologia do Museu Nacional, Universidade Federal do Rio de Janeiro, M. Sc. thesis, 131 p.

Cozzuol, M.A. 2006. The Acre vertebrate fauna: age, diversity, and geography. Journal of South American Earth Sciences, 21:185-203.

Donadío, O.E. 1984. Teídos del Mioceno temprano (Squamata, Sauria, Teiidae) de la Provincia de Santa Cruz, Argentina. Circular Informativa de la Asociación Paleontológica Argentina, 12:2-3.

Estes, R. 1961. Miocene lizards from Colombia, South America. Breviora, 143:1-8.

Estes, R. 1970. Origin of the Recent North American lower vertebrate fauna: an inquiry into the fossil record. Forma et Functio, 3:139-163.

Estes, R. 1983. Sauria terrestria, Amphisbaenia. In: P. Wellnhofer (ed.) Handbuch der Paläoherpetologie, Gustav Fischer Verlag, Teil 10A, 249 p.

Estes, R. \& Price, L. 1973. Iguanid lizard from Upper Cretaceous of Brazil. Science, 180:748-751.

Estes, R. \& Báez, A.M. 1985. Herpetofaunas of North and South America during the Late Cretaceous and Cenozoic: evidence for interchange? In: F.G. Stehli \& S.D. Webb (eds.) The Great American Biotic Interchange, Plenum Press, p. 139-197.

Estes, R.; de Queiroz, K. \& Gauthier, A. 1988. Phylogenetic relationships within Squamata. In: R. Estes \& G. Pregill (eds.) Phylogenetic relationships of the lizards families, Stanford University Press, p. 119-281.

Gao, K. \& Fox, R.C. 1991. New teiid lizards from the Upper Cretaceous Oldman Formation (Judithian) of southeastern Alberta, Canada, with a review of the Cretaceous record of teiids. Annals of the Carnegie Museum, 60(2):145-162.

Gray, J.E. 1827. A synopsis of the genera of saurian reptiles, in which some new genera are indicated, and the others reviewed by actual examination. Philosophical Magazine (Formerly: Annals of Philosophy), 2(2):54-58.

Hoffstetter, R. \& Gasc, J.P. 1969. Vertebrate and ribs of modern reptiles. In: C. Gans; A. d'A. Bellairs \& T.S. Parsons (eds.) Biology of the Reptilia, Morphology A, Academic Press, p. 201-310.

Hsiou, A.S. 2007. A new Teiidae species (Squamata, Scincomorpha) from the Late Pleistocene of Rio Grande do Sul State, Brazil. Revista Brasileira de Paleontologia, 10(3):181-194.

Hsiou, A.S.; Ferigolo, J. \& Albino, A.M. 2007. Sobre os Squamata (Lepidosauria) da Formação Solimões, Mioceno da Amazônia Sul-Ocidental, Brasil. Ameghiniana, Suplementos, 44(4):23R.

Hsiou, A.S. \& Albino, A.M. 2009. Presence of the genus Eunectes (Serpentes, Boidae) in the Neogene of Southwestern Amazonia, Brazil. Journal of Herpetology, 43(4):612-619. 
Kay, R.F., \& Madden, R.H. 1997. Paleogeography and paleoecology. In: R.F. Kay; R.H. Madden; R.L. Cifelli \& J.J. Flynn (eds.) Vertebrate paleontology in the neotropics - the Miocene fauna of La Venta, Colombia, Smithsonian Institution Press, p. 520-550.

Krause, L. 1985. Fossil record of the family Teiidae. Notes on paleobiogeography, current distribution, and habits of macroteiids (Sauria, Scincomorpha, Teiidae). Studies on Neotropical Fauna and Environment, 20:175-188.

Latrubesse, E.M.; Bocquentin, J.; Santos, C.R. \& Ramonell, C.G. 1997. Paleoenvironmental model for the late Cenozoic southwestern Amazonia: paleontology and geology. Acta Amazonica, 27(2):103-118.

Latrubesse, E.M.; Silva, S.A.F.; Cozzuol, M.A. \& Absy, M.L. 2007. Late Miocene continental sedimentation in southwestern Amazonia and its regional significance: biotic and geological evidence. Journal of South American Earth Sciences, 23: 61-80.

Nydam, R.L., \& Cifelli, R.L. 2002. A new teiid from the Cedar Mountain Formation (Albian-Cenomanian boundary) of Utah. Journal of Vertebrate Paleontology, 22(2):276-285.

Nydam, R.L.; Eaton, J.G. \& Sankey, J. 2007. New taxa of transversely-toothed lizards (Squamata: Scincomorpha) and new information on the evolutionary history of "teiids". Journal of Paleontology, 81(3):538-549.

Oppel, M. 1811. Die Ordnungen, Familien, und Gatungen der Reptilien. München, Joseph Lindauer, 87 p.

Paula-Couto, C. de. 1949. Novas observações sobre a paleontologia e geologia do depósito calcário de São José de Itaboraí. Rio de Janeiro, Departamento Nacional de Produção Mineral, Divisão de Geologia e Mineralogia, 13 p. (Notas Preliminares e Estudos 49).

Paula-Couto, C. de. 1958. Idade geológicas das bacias cenozóicas do Vale do Parnaíba e de Itaboraí. Boletim do Museu Nacional, n.s., Geologia, 25:1-17.

Pujos, F.; Albino, A.M.; Baby, P. \& Guyot, J.L. 2009. Presence of the extinct lizard Paradracaena (Teiidae) in the Middle Miocene of the Peruvian Amazon. Journal of Vertebrate Paleontology, 29(2):594-598.

Presch, W. 1974. A survey of the dentition of the macroteiid lizards (Teiidae: Lacertilia). Herpetologica, 30(4):344-349.

Souza-Cunha, F.L. \& Magalhães, R.M.M. 1986. A fauna de vertebrados sub-recentes de Cerca Grande, Matozinhos, Minas Gerais. In: CONGRESSO BRASILEIRO DE ZOOLOGIA, 6, 1986. Anais, Rio de Janeiro, SBZ, p. 119-131.

Sullivan, R.M. \& Estes, R. 1997. A reassessment of the fossil Tupinambinae. In: R.F. Kay; R.H. Madden; R.L. Cifelli \& J.J. Flynn (eds.) Vertebrate paleontology in the neotropics - the Miocene fauna of La Venta, Colombia. Smithsonian Institution Press, p. 100-112.

Vanzolini, P.E. \& Valencia, J. 1965. The genus Dracaena, with a brief consideration of macroteiid relantionships (Sauria, Teiidae). Arquivos de Zoologia, 13:7-40.

Received in August, 2009; accepted in November, 2009.

Appendix. Comparative material examined in this study: MCN-R 15215, Tupinambis merianae; MCN-D 298, T. merianae; MCN-D 300, T. merianae; MCN-D 301, T. merianae; MCN-D 303, T. merianae; MZUSP 12624, Dracaena guianensis; MZUSP 62849, D. paraguayensis; MZUSP 92131, T. duseni; MZUSP 84921, T. quadrilineatus; MZUSP 84928, T. quadrilineatus; MZUSP 93082, T. rufescens; MZUSP 93083, T. rufescens; MZUSP 93084, T. rufescens; MZUSP 92087, T. teguixin; MZUSP 92149, T. teguixin. 